\title{
The positive effect of black cumin ethanol extract (Nigella sativa) on decreasing serum TNF- $\alpha$ levels and interleukin-8 levels in mice model of preeclampsia.
}

\author{
Hamimatus Zainiyah $^{1 *}$, Ni Wayan Noviani ${ }^{2}$, Rubiati Hipni ${ }^{3}$ \\ ${ }^{1}$ Institute of Health Science, Ngudia Husada, Bangkalan, Madura, Indonesia \\ ${ }^{2}$ Obstetrics Academy, Denpasar, Bali, Indonesia \\ ${ }^{3}$ Polytechnic of Health Ministry of Health, Banjarmasin, South Kalimantan, Indonesia
}

\begin{abstract}
Background: During placental preeclampsia experiencing oxidative stress, oxidative stress can increase the expression and activation of nuclear factor-kappa $B$ which regulates the levels of TNF $\alpha$ (Tumor necrosis factor- $\alpha$ ), interleukin-6, interleukin-8, $C O X-2$ (Cyclooxygenase-2) genes.

Objective: Analyzing the positive effects of black cumin ethanol extract (Nigella sativa) on reducing serum TNF- $\alpha$ levels and serum interleukin-8 in mice model preeclampsia.

Methods: Research design True experimental with type post-test only control group design. Research using pregnant Balb/c strain mice was healthy used as preeclampsia model mice and divided into 6 groups. Ethanol extract of seeds is Nigella sativa gave orally in the treatment group from 15 to $19 \mathrm{~d}$ at a dose of $500 \mathrm{mg} \mathrm{kg} / \mathrm{d}, 1000 \mathrm{mg} / \mathrm{kg} / \mathrm{d}$. $1500 \mathrm{mg} / \mathrm{kg} / \mathrm{d}, 2000 \mathrm{mg} / \mathrm{kg}$ body weight $/ \mathrm{d}$, and terminated at $20^{\text {th }}$ gestational age. Measurement of TNF- $\alpha$ levels and Interleukin-8 levels using ELISA (Enzyme-linked immune sorbent assay).

Results: TNF- $\alpha$ levels and interleukin-8 levels showed a decreased level after being given treatment at a dose of $1500 \mathrm{mg} / \mathrm{kg}$ body weight.

Conclusions: Black cumin extract has a positive effect to reduce serum TNF- $\alpha$ and serum interleukin-8 levels to be used as a therapy for preeclampsia disorders.
\end{abstract}

Keywords: TNF- $\alpha$ levels, Interleukin-8, Black cumin extract, Preeclampsia.

Accepted on November 26, 2018

\section{Introduction}

Preeclampsia in pregnancy that can be experienced by pregnant women varies from mild hypertension, severe hypertension, eclampsia to hemolysis syndrome, elevated liver enzymes, low platelet count, endothelial dysfunction in the body such as in the kidneys, liver, heart and brain. The impact of preeclampsia is preterm birth, intrauterine growth retardation and fetal death [1].

The incidence of preeclampsia is approximately $5-8 \%$ of all pregnancies, the incidence of preeclampsia in the second pregnancy is less than $1 \%$ of pregnant women with normal blood pressure during the first pregnancy [2]. Preeclampsia complicates $1.3 \%-6.7 \%$ of all pregnancies and the main cause of maternal and perinatal morbidity and mortality worldwide [3-5]. Three classic causes of maternal death are an infection, bleeding, and preeclampsia [6]. Based on the Indonesian Demographic and Health Survey year of maternal mortality in Indonesia for the period 2008-2012 was 359 deaths per 100,000 live births higher than the results of the 2007 which amounted to 228 per 100,000 live births. The incidence of preeclampsia is said to be a public health problem if the case fatality rate of preeclampsia reaches $1.4 \%$ to $1.8 \%$. In Indonesia, the frequency of preeclampsia is around 3-10\% [7].

The initial cause of preeclampsia is still unknown because preeclampsia is "the disease of theories" [8]. Preeclampsia is one of the complications in pregnancy whose clinical findings are characterized by an increase in blood pressure accompanied by proteinuria in pregnant women with gestational age above $20 \mathrm{w}$ who previously had no history of previous hypertension [9-12]. The cause of preeclampsia is the molecular mechanism of abnormal development, placental hypoxia, and endothelial dysfunction. Cytokines are intermediate proteins released by immune cells that function to regulate or stimulate other body's immune cells. Several types of cytokines have been shown to increase in preeclampsia and may be used as a marker of preeclampsia $[8,13]$.

During placental preeclampsia experiencing oxidative stress, oxidative stress can increase the expression and activation of $\mathrm{NF}-\kappa \mathrm{B}$ (nuclear factor-kappa $\mathrm{B}$ ) which regulates the levels of TNF $\alpha, \quad$ interleukin-6, interleukin-8, and COX-2 
(Cyclooxygenase-2) genes. In preeclampsia, there is an increase in NF-kB in trophoblast cells that experience oxidative stress $[14,15]$.

Black cumin (Nigella sativa) as an anti-inflammatory and antioxidant. The results of chemical analysis of black cumin oil showed that the fixed oil content of line oleic acid, oleic acid, eicosanoat acid, palmitoleic acid, palmitic acid, stearic acid, myristic acid, sterols, and volatile oil showed the main active ingredient, thymoquinone (2-isopropyl- 5-methylbenzoquinone) proved to have anti-inflammatory activity [16]. The main components of black cumin seeds, thymoquinone, have the ability to inhibit pro inflammatory cytokines such as TNF- $\alpha$, interleukin-1, interleukin-6, NF-kB (nuclear factorkappa B) [17-19]. Thymoquinone works as an inflammatory inhibitor that works through the pathway as an antiinflammatory. The inflammatory immune response starts from the recruitment of inflammatory cells into the inflammatory lesion [20-22].

\section{Materials and Methods}

\section{Research}

Design true experimental research design with post-test only control group design, researchers measured the effect of treatment on the experimental group by comparing the control group, without first pretesting [23]. Research using pregnant mice was injected with serum of severe preeclampsia mothers and serum of normal pregnant women, using human serum to be injected in pregnant mice to obtain symptoms of preeclampsia in mice that had received ethical approval from the ethics committee of the Brawijaya University Faculty of Medicine.

Healthy mice were used as mice that approached the preeclampsia model by injecting with serum of severe preeclampsia mothers and divided into 6 groups, with the details of the control group in group 1 of normal pregnant mice, group 2 of preeclampsia mice and the treatment group which was given a group of black cumin ethanol extract. 3: dose of $500 \mathrm{mg} / \mathrm{kg}$ body weight/d, in group 4: dose 1000 $\mathrm{mg} / \mathrm{kg}$ body weight/d, in group 5: dose $1500 \mathrm{mg} / \mathrm{kg}$ body weight/d and in group 6: dose $2000 \mathrm{mg} / \mathrm{kg}$ body weight/d, increase in dose for each group given with a counting series with a difference of $500 \mathrm{mg}$ from the previous dose. The duration of giving black cumin extract is given orally from the 15 th to $20^{\text {th }} \mathrm{d}$ of gestation [24,25].
The process of making black cumin extract through 3 stages: the drying process, the extraction process (the results of this extract will be used in the study of this extract in the form of thick liquid (dark oil) and dark brown close to $100 \mathrm{cc}$ black, active substance concentration this extract is $100 \%$ ) and, the evaporation process.

\section{Measurement of tumor necrosis factor- $\alpha(T N F-\alpha)$}

Tool: Micropipette, blue, yellow, and white tip, vortex, dependent, ELISA (Enzyme-linked immuno sorbent assay) reader, computer with MS. Excell. Material: Serum mouse control and treatment group and ELISA (Enzyme-linked immuno sorbent assay). Measurement of TNF- $\alpha$ levels using ELISA (Enzyme-linked immuno sorbent assay) (Bio Legend, catalog number 430907).

\section{Measurement of interleukin-8 (interleukin-8)}

Tool: Micropipette, blue, yellow, and white tip, vortex, shaker mixer, incubator, ELISA (Enzyme-linked immuno sorbent assay) reader, computer with MS. Excell.Ingredients: Serum mouse samples of animal samples both control and treatment groups and ELISA KIT. BioLegend's Interleukin 8 (interleukin-8) ELISA (Enzyme-linked immuno sorbent assay) measurement, E1481Mo catalog number).

\section{Statistical analysis}

All the data was recorded in the entry form, and further organized using descriptive statistics, presented as mean $\pm \mathrm{SD}$ for numerical data, and proportion (\%) for the categorical data. The statistical analysis was carried out by using ANOVA one way and continuous using (Multiple comparisons) with the least significant difference (LSD). Values of $\mathrm{p}<0.05$ were considered statistically significant.

\section{Result}

\section{General overview of mice preeclampsia model}

Making mice model of preeclampsia refers to research conducted $[24,26]$. To evaluate the characteristics of preeclampsia with hypertension and positive urinary protein. The basic characteristics of mice in each control group and treatment group can be seen in the Table 1. Basic characteristics are homogeneous according to inclusion and exclusion criteria.

Table 1. Baseline characteristics of mice preeclampsia model.

\begin{tabular}{|c|c|c|c|c|c|c|}
\hline Characteristics & K (-) & $K(+)$ & PI & P2 & P3 & P4 \\
\hline & (Mean \pm SD) & (Mean \pm SD) & (Mean \pm SD) & (Mean \pm SD) & (Mean \pm SD) & $($ Mean $\pm S D))$ \\
\hline Number of groups & 5 & 5 & 5 & 5 & 5 & 5 \\
\hline BB initial & $25.6 \pm 1$ & $25 . \pm 1.2$ & $26.6 \pm 41.6$ & $27.4 \pm 0.5$ & $27 \pm 0.9$ & $26.4 \pm 1.6$ \\
\hline BB end & $38.6 \pm 3.6$ & $39.6 \pm 2$ & $41.6 \pm 3.9$ & $41.8 \pm 2.1$ & $42 \pm 3.9$ & $39 \pm 1.4$ \\
\hline
\end{tabular}


The positive effect of black cumin ethanol extract (Nigella sativa) on decreasing serum TNF-a levels and interleukin-8 levels in mice model of preeclampsia

\begin{tabular}{lllllll}
\hline Systolic pressure & $118.4 \pm 6.4$ & $170.1 \pm 0.7$ & $174.4 \pm 13.7$ & $160.2 \pm 9.1$ & $166 \pm 7.7$ & $163.6 \pm 11.3$ \\
\hline Diastolic pressure & $79.8 \pm 0.4$ & $78.8 \pm 1.5$ & $79.4 \pm 0.8$ & $77.8 \pm 3.9$ & $79 \pm 0.9$ & $79.2 \pm 0.7$ \\
\hline Urine protein & $4.8 \pm 1.21$ & $12.2 \pm 0.7$ & $12.8 \pm 1.3$ & $14.3 \pm 0.7$ & $12.4 \pm 1.1$ & $11.8 \pm 2$ \\
\hline
\end{tabular}

The results showed that the mice had positive control and the group that would be treated after the injection of severe preeclampsia mothers on the $10^{\text {th }}$ and $11^{\text {th }} \mathrm{d}$ and on the $15^{\text {th }} \mathrm{d}$ were measured blood pressure and urine protein had hypertension and urine protein levels were higher than negative controls.

Negative group $\left(\mathrm{K}^{-}\right)$and positive control group $\left(\mathrm{K}^{+}\right)$ maintained for $20 \mathrm{~d}$ by feeding and drinking as usual, while the treatment group exposed to various doses of ethanol extract of seeds Nigella sativa in pregnant mice with a dose of group 1: dose of $500 \mathrm{mg} / \mathrm{kg}$ body weight/d, in group 2: dose 1000 $\mathrm{mg} / \mathrm{kg}$ body weight/d, in group 3: dose $1500 \mathrm{mg} / \mathrm{kg}$ body weight/d and in group 4: dose $2000 \mathrm{mg} / \mathrm{kg}$ body weight/d for 5 days on the $20^{\text {th }} \mathrm{d}$ termination was done for good mouse mice negative control group $\left(\mathrm{K}^{-}\right)$and positive control group $\left(\mathrm{K}^{+}\right)$ and treatment for serum TNF- $\alpha$ levels and serum interleukin- 8 levels serum collection results stored at $-40^{\circ} \mathrm{C}$ numbering on the cap and arranged for measurement ELISA (Enzyme-linked immunosorbent assay). The results of serum surgery of mice model of preeclampsia with negative control group, positive control group, treatment group dose 1: dose as much as 500 $\mathrm{mg} / \mathrm{kg}$ body weight/d, treatment group dose 2: dose 1000 $\mathrm{mg} / \mathrm{kg}$ body weight/d, treatment group dose 3: dose 1500 $\mathrm{mg} / \mathrm{kg}$ body weight/d and treatment group dose 4: dose 2000 $\mathrm{mg} / \mathrm{kg}$ body weight/d can be seen in the picture below (Figure $1)$.

\section{Collection of serum samples of mice negative control, positive control and treatment}

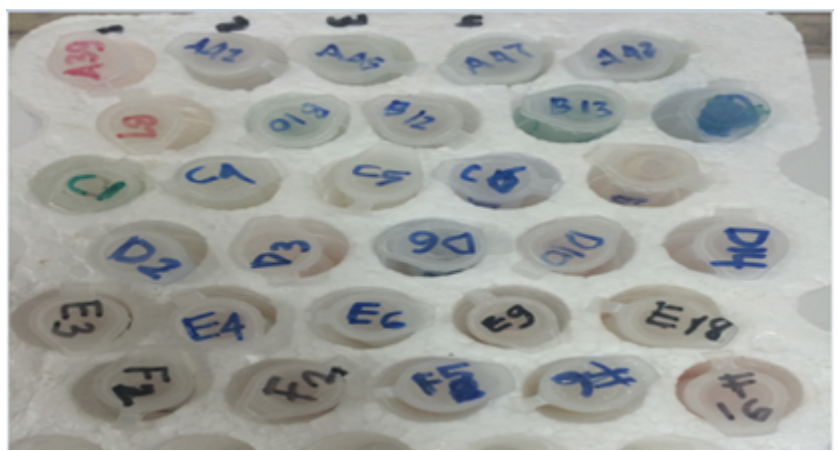

Figure 1. Number. A39, A41, A45, A47, A48 negative controls; number. B.7, B.10, B.12, B.13, B.19 Positive control, number. C.1, C. 4, C.5, C.6, C.9: PE model mice with black cumin ethanol extract 500 $\mathrm{mg} / \mathrm{Kg}$ body weight, Number D.2, D.3, D.6, D. 10, D.14 mice model $P E$ with black cumin extract $1000 \mathrm{mg} / \mathrm{kg}$ body weight, number. E.3, E.4, E.6, E.9, E.18: PE models with black cumin extract $1500 \mathrm{mg} / \mathrm{kg}$ body weight, number. F.2, F.3, F.5, F.6, F.16 PE model mice with 2000 $\mathrm{mg} / \mathrm{kg}$ body weight black cumin ethanol extract.

\section{Results of measurement of serum TNF- $\alpha$ levels}

Based on the results of the test one-way ANOVA on TNF- $\alpha$ levels obtained there were significant differences in the mean levels of TNF- $\alpha$ the five observation sample groups, this was indicated by $\mathrm{p}$-value $=0.000<\alpha$. Furthermore, in the multiple comparisons test with the test, it is least significant difference (LSD) obtained and displayed in full in the table below (Table 2).

Table 2. Comparison of TNF- $\alpha$ level $(\mathrm{pg} / \mathrm{ml})$.



Description: At (Mean $\pm S D$ ) if you load different letters, their differences are significant ( $p$-value $<0.05$ ) and if you load the same letter, there is no significant difference ( $p$-value>0.05).

The results showed that the treatment of extract ethanol Nigella sativa various doses of had a significant effect on decreasing levels of TNF- $\alpha$ in models of preeclampsia. Similarly, the dose obtained ethanol extract of Nigella sativa optimum lower levels of TNF- $\alpha$ is a $1500 \mathrm{mg}$ dose.

\section{Results of measurement of serum interleukin-8 levels}

Based on the results of the one way ANOVA test on serum interleukin-8 levels data, there was a significant difference in the mean serum interleukin- 8 levels of the five observation sample groups, this was indicated by p-value $=0.007<\alpha$. Furthermore, in the multiple comparisons test with the least significant difference (LSD) test, it is obtained and displayed in full in the table below (Table 3 ).

Table 3. Comparison of serum interleukin-8 levels.

\begin{tabular}{|c|c|c|c|}
\hline Observation group & $\mathbf{n}$ & (Mean \pm SD) & p-value \\
\hline Positive control (PEB) & 5 & $186.43 \pm 7.53^{a}$ & $0.007<\alpha$ \\
\hline PEB+ethanol extract ns $500 \mathrm{mg}$ & 5 & $140.66 \pm 22.47^{b}$ & \\
\hline $\begin{array}{l}\text { PEB+ethanol extract ns } 1000 \\
\text { mg }\end{array}$ & 5 & $154.60 \pm 24.75^{b}$ & \\
\hline
\end{tabular}


PEB+ethanol extract ns $1500 \quad 5 \quad 147.20 \pm 10.39^{b}$

$\mathrm{mg}$

PEB+extract ethanol ns $2000 \quad 5 \quad 130.34 \pm 33.17^{\mathrm{b}}$

$\mathrm{mg}$

Description: In (Mean $\pm S D$ ) if you contain different letters means there are significant differences ( $p$-value $<0.05)$ and if you load the same letter means there is no significant difference ( $p$-value> 0.05).

Based on the description of the research results it can be interpreted that the treatment of extract ethanol Nigella sativa various doses of has a significant effect on the reduction of interleukin-8 levels in mice modeled in preeclampsia. Likewise, a dose of ethanol extracts Nigella sativa the most optimum was reduced to $1500 \mathrm{mg}$.

\section{Discussion}

\section{Positive effects of black cumin ethanol extract (Nigella sativa) on decreasing serum TNF- $\alpha$ levels in mice model of preeclampsia}

This study shows that there are significant differences in mean TNF- $\alpha$ levels between positive control group (model of preeclampsia mice) $\left(47.91 \pm 6.32^{\mathrm{a}} \mathrm{pg} / \mathrm{ml}\right)$ with the treatment group giving ethanol extract Nigella sativa $500 \mathrm{mg}$ of (31.64 \pm $\left.1.87100022 .68^{\mathrm{b}} \mathrm{pg} / \mathrm{ml}\right)$, with a dose of $\left.\pm 3.46^{\mathrm{c}} \mathrm{pg} / \mathrm{ml}\right)$, at a dose of $1500 \mathrm{mg}\left(9.29 \pm 1.93^{\mathrm{d}} \mathrm{pg} / \mathrm{ml}\right)$, and also at a dose of $2000 \mathrm{mg}\left(15.66 \pm 2.14^{\mathrm{e}} \mathrm{pg} / \mathrm{ml}\right)$. Effect of extract ethanol Nigella sativa is able to reduce levels of TNF- $\alpha$.There was a decrease in TNF- $\alpha$ levels along with an increase in the dose of ethanol extract Nigella sativa given to mice in the preeclampsia model. So the second hypothesis has been proven, the ethanol extract of Nigella sativa can reduce levels of TNF- $\alpha$ in mice model of preeclampsia.

Furthermore, there is also a significant difference mean levels of TNF- $\alpha$ between the treatment groups of ethanol extract Nigella sativa $500 \mathrm{mg}\left(31.64 \pm 1.87^{\mathrm{b}} \mathrm{pg} / \mathrm{ml}\right)$ with treatment group ethanol extract Nigella sativa $1000 \mathrm{mg}\left(3: 46 \pm 22.68^{\mathrm{c}}\right.$ $\mathrm{pg} / \mathrm{ml}$ ), with the group treatments extract ethanol of Nigella sativa $1500 \mathrm{mg}\left(9: 29 \pm 1.93^{\mathrm{d}} \mathrm{pg} / \mathrm{ml}\right)$, and also to the treatment group of ethanol extract Nigella sativa $2000 \mathrm{mg}\left(15.66 \pm 2: 14^{\mathrm{e}}\right.$ $\mathrm{pg} / \mathrm{ml}$ ). If based on the mean value, it can be seen that there is a decrease in the mean level of TNF- $\alpha$ along with the increase in the dose of ethanol extract Nigella sativa to the mouse preeclampsia model, except at a dose of $2000 \mathrm{mg}$ increased slightly.

Furthermore, at a dose of $1000 \mathrm{mg}, 1500 \mathrm{mg}$, and $2000 \mathrm{mg}$ of ethanol extract Nigella sativa also showed a significant difference in the mean levels of TNF- $\alpha$ in the mice model of preeclampsia. If based on the mean value of TNF- $\alpha$ levels in the treatment group $1500 \mathrm{mg}$ dose showed the smallest average value of TNF- $\alpha\left(9.29 \pm 1.93^{\mathrm{d}} \mathrm{pg} / \mathrm{ml}\right)$ compared to groups at other doses. This means that the treatment of ethanol extract Nigella sativa $1500 \mathrm{mg}$ dose can is considered the most optimum dose in reducing TNF- $\alpha$ levels in mice model of preeclampsia.
Based on the description of the study it can be interpreted that the treatment of extract ethanol Nigella sativa various doses of had a significant effect on decreasing levels of TNF- $\alpha$ in mice model of preeclampsia. So the second research hypothesis has been proven, namely the administration of extract ethanol Nigella sativa can reduce levels of TNF-ain mice model of preeclampsia. Similarly, the dose obtained ethanol extract of Nigella sativa optimum lower levels of TNF- $\alpha$ is a $1500 \mathrm{mg}$ dose.

Proinflammatory cytokines such as TNF- $\alpha$ and interleukin-6 are higher in preeclampsia patients when compared with normal pregnant patients [27]. High levels of interleukin-6 will induce differentiation from $\mathrm{T}$ cells to Th17 cells, followed by a decrease in the regulatory function of Treg so that the Th17: Treg ratio. Furthermore, this condition will activate the response and differentiation of B cells to CD19+CD5 + B cells. This type of B cell is an autoreactive B cell that can secrete high AT1AA in preeclampsia patients. The AT1-AA formed will bind to the AT1 receptor (AT1R) which returns to induce TNF- $\alpha$ and sFlt-1 [24,25]. TNF- $\alpha$ binds TNFR1 and TNFR2 with high affinity. Human TNF- $\alpha$ receptors can bind to TNF- $\alpha$ receptors in some specific species such as TNFR1 in mice [28].

Other studies that have been conducted show that the serum ability of preeclamptic patients to increase sFlt-1 and production in endothelial cell cultures is inhibited by the administration of anti-TNF- $\alpha$ drugs. So it can be concluded that TNF- $\alpha$ can directly increase the production of sFlt-1 and [25].

Nigella sativa has the main active ingredient, thymoquinone has the ability to inhibit proinflammatory cytokines such as $\mathrm{TNF} \alpha$, interleukin-1, interleukin-6, NF-k $\beta$ [17-19]. Thymoquinone works as an inflammatory inhibitor that works through the pathway as an anti-inflammatory and proapoptotic.

TNF- $\alpha$ is a proinflammatory cytokine that plays an important role in this process. The NF-к $\beta$ pathway is activated by TNF $\alpha$, thymoquinone works to inhibit NF-к $\beta$ which is activated by TNF $\alpha$ and inhibits NF-к $\beta$ translocation to PDA cell nuclei (Ductal adenocarcinoma) pancreatic [20-22]. So that it can be explained that the administration of ethanol extract Nigella sativa in mice model of preeclampsia has been shown to reduce serum TNF- $\alpha$ levels.

\section{Positive effects of black cumin ethanol extract (Nigella sativa) on decreasing serum interleukin-8 levels in mice model of preeclampsia}

Based on multiple comparison test results with test LSD (Least significant difference) showed that there were significant differences in serum interleukin-8 levels between positive control group (model of preeclampsia mice) $\left(186.43 \pm 7.53^{\mathrm{a}}\right.$ $\mathrm{ng} / \mathrm{L}$ ) with the treatment group administration of ethanol extract Nigella sativa dose of $500 \mathrm{mg}\left(140.66 \pm 22.47^{\mathrm{b}} \mathrm{ng} / \mathrm{L}\right)$, with a dose of $1000 \mathrm{mg}\left(154.60 \pm 24.75^{\mathrm{b}} \mathrm{ng} / \mathrm{L}\right)$, with a dose of $1500 \mathrm{mg}\left(147.20 \pm 10.39^{\mathrm{b}} \mathrm{ng} / \mathrm{L}\right)$, and also at a dose of $2000 \mathrm{mg}$ $\left(130.34 \pm 33.17^{\mathrm{b}} \mathrm{ng} / \mathrm{L}\right)$. This means that there is an effect of treatment with of ethanol extracts of Nigella sativa $500 \mathrm{mg}$, 
$1000 \mathrm{mg}, 1500 \mathrm{mg}$, and $2000 \mathrm{mg}$ on decreasing serum interleukin-8 levels in models of preeclampsia. The administration of extract ethanol Nigella sativa various doses of had a significant effect on lowering serum interleukin- 8 levels in models of preeclampsia.

Thymoquinone inhibits transcription of NF-kB by reducing its promoter activity, first inhibits the NF-kB signaling pathway and inhibits its transcription and inhibits transcription of cytokines and inflammatory chemokines such as interleukin-8, thymoquinone as an inhibitor of inflammatory pathways which is a combination as anti-inflammatory and anti-apoptosis. Administration of thymoquinone after administration of $6 \mathrm{~h}$ and $24 \mathrm{~h}$ can reduce interleukin- 8 and after $24 \mathrm{~h}$ of administration completely eliminates interleukin- 8 expression [17-19].

TQ is the most bioactive ingredient of black seed oil which inhibits the expression and activity of NF-kB, the exact mechanism by which thymoquinone regulates interleukin- 8 and cancer cell growth. Treatment of interleukin- 8 thymoquinone-suppressing and its receptors in hepatocellular carcinoma (HCC).

The results of this study showed that the administration of black cumin reduced interleukin-8 in serum in models of preeclampsia mice through suppression of dysflex NF-kB expression and inhibition of NF-kB p65 activation in the cell so transcription did not occur. Proinflammatory gene (interleukin-8). The dose of ethanol extract of Nigella sativa optimum was obtained which was $2000 \mathrm{mg}$ dose.

In this study, the ethanol extract of black cumin seeds dose $2000 \mathrm{mg} / \mathrm{kg}$ body weight/d there was an increase in interleukin-6 levels, this might be due to the effects of hormesis, biphasic dose response wherein low doses give a beneficial effect and at high doses have a detrimental effect or toxic effect [29]. This is due to the response of cells or organisms at low doses to be considered as an adaptive compensation process following the initial disruption of homeostasis. Many articles published data showing biphasic responses to cells, organisms or changes in environmental conditions. Calabrase et al. also described the meta-analysis of biphasic dose-response curves. Although not all factors can cause biphasic dose response in cells and organisms but there are several things that are common. Examples include exposure to chemicals, changes in temperature, the presence of radiation, activities, energy/food intake and others [30].

\section{Conclusion}

Various doses of ethanol extract of Nigella sativa had a significant effect on decreasing levels of TNF- $\alpha$ in models of preeclampsia. Similarly, the dose obtained ethanol extract of Nigella sativa optimum lower levels of TNF- $\alpha$ is a $1500 \mathrm{mg}$ dose. The administration of extract ethanol Nigella sativa various doses of had a significant effect on lowering serum interleukin-8 levels in models of preeclampsia. TNF- $\alpha$ levels and interleukin- 8 levels showed a decreased level after being given treatment at a dose of $1500 \mathrm{mg} /$ body weight.

\section{Limitation of Research}

No further examination of the content of black cumin is carried out after extraction so that the dose becomes more accurate.

\section{References}

1. Karumanchi SA, Maynard SE, Stillman IE, Epstein FH, Sukhatme VP. Preeclampsia: a renal perspective. Kidney Int 2005; 67: 2101-2113.

2. Kalkunte S, Boij, R, Norris W, Friedman J, Lai Z, Kurtis J, Matthiesen L. Sera from preeclampsia patients elicit symptoms of human disease in mice and provide a base for an in vitro predictive assay. Am J Pathol 2010; 177: 2387-2398.

3. Conde-Agudelo A, Romero R, Kusanovic JP, Hassan SS. Supplementation with vitamins $\mathrm{C}$ and $\mathrm{E}$ during pregnancy for the prevention of preeclampsia and other adverse maternal and perinatal outcomes: a systematic review and meta-analysis. Am J Obstet Gynecol 2011; 204: 503.

4. Vinterleukinlar J, Say, L, Gulmezoglu M, Merialdi M, Lindheimer M, Betran AP. Eclampsia and preeclampsia: a health problem for 2000 years. Res Gate 2003; 32: 189-207.

5. Lindheimer MD, Taler SJ, Cunningham FG. Hypertension in pregnancy. J Am Soc Hypertens 2010; 4: 68-78.

6. Prawirohardjo S. Midwifery. Wailey Online 2014; 35: 531-545.

7. IDHS. Survey demographics of Indonesian health 2012.

8. Cunningham LBHRS. Winterleukinliams Obstetrics (3rd Edn.) Access ObGyn 2010; 45: 45-67.

9. Wang A, Rana S, Karumanchi SA. Reviews preeclampsia: the role of angiogenic factors in its pathogenesis. Physiology 2009; 1: 147-158.

10. Skjaerven R. Recurrence of pre-eclampsia across generations: exploring fetal and maternal genetic components in a population-based cohort. British Med J 2005; 331: 877-932.

11. Hladunewich M, Karumanchi, SA, Lafayette R. Pathophysiology of the clinical manifestations of preeclampsia. Clin J Am Soc Nephrol CJASN 2007; 2: 543-549.

12. Young BC, Levine RJ, Karumanchi SA. Pathogenesis of preeclampsia. Annu Rev Pathol 2010; 5: 173-192.

13. Stillman IE, Karumanchi SA. The glomerular injury of preeclampsia. J Am Soc Nephrol 2007; 18: 2281-2284.

14. Vaughan JE, Walsh SW. Activation of NF- $\hat{I}^{\circ} B$ in placentas of women with preeclampsia. Hypertens Pregnancy 2012; 31: 243-251.

15. Rochelson B. Magnesium sulfate suppressant inflammatory responses by human umbInterleukinical vein endothelial cells (HuVECs) through the NF_B pathway. J Reprod Immunol 2007; 73: 101-107.

16. Wajid N. Dual properties of Nigella Sativa: anti-oxidant and pro-oxidant. Life Sci 2014; 1: 9-18. 
17. Boskabady MH. The effect of Nigella sativa extracts on tracheal responsiveness and lung inflammation in ovalbumin-sensitized guinea pigs. Clinics 2011; 66: 879-887.

18. Chehl N. Anti-inflammatory effects of the Nigella sativa seed extract, thymoquinone, in pancreatic cancer cells. HPB Off J Int Hepato Pancreato BInterleukiniary Assoc 2009; 11: 373-381.

19. Michel CG, El-Sayed NS, Moustafa SF, Ezzat SM, Nesseem DI, El-Alfy TS. Phytochemical and biological investigation of the extracts of Nigella sativa L. seed waste. Drug Test Anal 2011; 3: 245-254.

20. Mohammed SS. The possible protective effect of nigella sativa ointerleukin against piroxicam-induced gastric mucosal damage in adult male Albino rats. Light Scanning Electron Microscopic Study 2010; 33: 127-139.

21. Nature M, Galav V. Anti-inflammatory effect and toxicological evaluation of thymoquinone (VolatInterleukine ointerleukin of black seed) on adjuvant-induced arthritis in wistar rat. Drug Test Anal 2013; 3: 17-22.

22. Perveen T, Haider S, Zuberi NA, Saleem S, Sadaf S, Batool Z. Increased 5-HT levels following repeated administration of Nigella sativa L. (Black seed) oil produce antidepressant effects in rats. Sci Pharm 2013; 82: $161-170$.

23. Notoadmodjo S. Health Research Methodology. Jakarta Rineka Cipta 2010; 3: 50-58.

24. Wicaksono BA, Candra S, Baktiyani W, Fitri LE. Intraperitoneal injection of high TNF (TNF-a) serum increases soluble fms-like tyrosine kinase 1 (sFLT-1) and blood pressure of pregnant mice. J Trop Life Sci 2015; 5: 45-49.

25. Zhou CC. TNF induction contributions to increased soluble endoglin production in preeclampsia. Circulation 2010; 5: 34-56.

26. Kalkunte S, Boij R, Norris W, Friedman J, Lai Z, Kurtis J. Sera from preeclampsia patients with severe symptoms of human disease in mice and providing a basis for in vitro predictive assays. Am J Pathol 2010; 177: 2387-2398.

27. LaMarca B, Wallukat G, Llinas M, Herse F, Dechend R, Granger JP. Autoantibodies to the angiotensin type I receptor in response to placental ischemia and tumor necrosis factor alpha in pregnant rats. Hypertension 2008; 52: 1168-1172.

28. Parameswaran N, Patial S. NIH Public Access. PMC 2012; 29: 997-1003.

29. Mattson MP. Hormesis defined. Ageing Res Rev 2008; 7 : 1-7.

30. Calabrase EJ, Baldwin LA. Chemical hormesis: its historical foundations as a biological hypothesis. Toxicol Pathol 1999; 27: 195-216.

\section{*Correspondence to}

Hamimatus Zainiyah

Institute of Health Science Ngudia Husada

Bangkalan

Indonesia 